Jan Daniel Szczurek

ORCID: https://orcid.org/0000-0002-9804-0566

The Pontifical University of John Paul II in Krakow, Poland

\title{
The Service of Thought. \\ The First Decade of the Pontifical University of John Paul II in Krakow
}

\begin{abstract}
The paper shows how "the service of thought" (using an expression of John Paul II) has been performed at the Pontifical University of John Paul II in Krakow during last ten years. This paper presents the main cyclical scientific events, such as conferences and symposia, as well as signs of growth of the unique pontifical university in Central and Eastern Europe. For example the "Krakow methodological conferences" are of particular interest, because the discovery of an appropriate method ensures success in the search for truth.
\end{abstract}

\section{Keywords}

The Pontifical University of John Paul II in Krakow, ecclesiastical university education, "service of thought".

The Pontifical University of John Paul II is an academic institution located in Krakow, derived from the Faculty of Theology established in the 14th century. It happened exactly in 1397 when the Queen of Poland St. Jadwiga (Hedwig) asked the Pope Boniface IX to strengthen the Krakow Studium Generale (founded on 12 May 1364 by King Casimir the Great) by founding the Faculty of Theology. The Pope answered on 11 January 1397 with the Bull Eximiae devotionis affectus 
allowing the foundation of that Faculty in Krakow at the same time promoting the Studium to the rank of university (now the Jagiellonian University). ${ }^{1}$ This very date begins an above six hundred years' period of history of the Faculty of Theology in Krakow.

Unfortunately, in 1954 under the atheistic government the Faculty of Theology was removed from the Jagiellonian University, but neither the then Metropolitan of Krakow Card. K. Wojtyla nor the Apostolic See had adopted this decision. Thanks to the efforts of the Cardinal of Krakow the Faculty functioned as an independent ecclesiastical academic school and in 1959 the Apostolic See stated in a decree that the Faculty of Theology "remains under the supervision of one ecclesiastic authority and in the future is to be formed according to the laws passed by the Apostolic See." This authority was represented by Card. K. Wojtyla and owing to his efforts in 1974 the Faculty was promoted to the Pontifical Faculty of Theology. ${ }^{3}$

A turning point in the history of our University falls on December 8, 1981, when the pope John Paul II issued a "motu proprio" Beata Hedvigis. ${ }^{4}$ In its virtue, the Pontifical Academy of Theology was founded. It was composed of three faculties (departments): the Faculty of Theology, the Faculty of Philosophy and the Faculty of Church History. During his meeting with the rectors of the polish universities on June 8, 1997 in Krakow the Pope remembered that event in this words: "Despite numerous difficulties and obstacles on the part of the Authorities, the Faculty continued to exist and function at the Major Seminary of Krakow. First as a Pontifical Faculty of Theology. Later the situation evolved to the point that the Pontifical Academy of Theology could be established in Krakow as an athenaeum made up of three faculties,

${ }^{1}$ Bulla Bonifatii pp. IX, Facultatem Theologicam in Studio Generali Cracoviensi instituens, "Analecta Cracoviensia" 9 (1977), p. 7.

2 “Apostolica Sedes [...] declaravit" Facultatem Theologicam "sub unius Ecclesiasticae Auctoritatis regimine manere atque in posterum ad normam legum ab Apostolica Sede latarum unice conformandam atque moderandam esse". Sacra Congregatio de Seminariis et Studiorum Universitatibus, Decretum, no. 2295/59/4 (December 16, 1959). Archive Pontifical University of John Paul II in Krakow, no. 0110. This Decree was not published in the "Acta Apostolicae Sedis" (cf.: AAS 51 (1959), p. 948; 52(1960), p. 1044; 53(1961), p. 850).

${ }^{3}$ Sacra Congregatio pro Institutione Catholica, Decretum. Facultati Sacrae Theologiae Cracoviensi (Krakow) titulus «Pontificius» confertur, AAS 67(1975), p. 149-150.

${ }^{4}$ Ioannes Paulus pp. II, Litterae Apostolicae motu proprio datae. Pontificia Academia Theologica Cracoviensis constituitur, AAS 74(1982), p. 369-372. 
in spiritual continuity with the ancient Theology Faculty of the Jagiellonian University." So the Academy, and then the University, continue the almost six hundred years heritage of the Faculty of Theology of the Jagiellonian University. In that memorable address the Pope defined the essence of every university in this short expression: "the service of thought". He said: "There are few things as important in human life and society as the service of thought. The «service of thought» to which I am alluding is essentially nothing other than the service of truth in its social aspect. Every intellectual, independently of his personal convictions, is called to let himself be guided by this sublime and difficult ideal and to function as a critical conscience regarding all that endangers humanity or diminishes it." ${ }^{\prime 6}$ All the activity of our University is led by this idea expressed by the evangelical order: Euntes docete ("Go therefore and make disciples", Mat 28:19), which was previously chosen as invocation to the university banner.

The last significant event, which constitutes the reference point for this paper, is the promotion of Pontifical Academy of Theology to the Pontifical University of John Paul II, on June 19, 2009 (the liturgical solemnity of Sacred Heart of Jesus). The Congregation for Catholic Education (for Seminaries and Institutes of Scientific Research) communicated in a letter that "bowing to the requests of the most eminent and most venerable Cardinal Stanislaw Dziwisz [...], Pope Benedict XVI, to honor the memory of his illustrious predecessor the Servant of God John Paul II, decided that the Pontifical Academy of Theology in Krakow be raised to the dignity of the Pontifical University of John Paul II in Krakow for the development of the ecclesiastical sciences." This decision did not change anything in the structure and the goals of the Pontifical University in relation to those of the Pontifical Academy. Therefore the University continued to comply with the provisions laid down in the apostolic constitution Sapientia christiana

${ }^{5}$ John Paul II, Meeting with the Rectors of the Polish Universities. Address, no. 3, Collegiate Church of Saint Ann (8 June 1997), http://w2.vatican.va/content/john-paul-ii/en/speeches/1997/ june/documents/hf_jp-ii_spe_19970608_ato-academico.html (July 22, 2019).

${ }^{6}$ Ibidem, no. 5 .

7 "Attentis postulationibus Em.mi ac Rev.mi carinalis Stanislai Dziwisz [...] Summus Pontifex Benedictus XVI, ad honorandam memoriam sui insignis Praedecessoris servi Dei Ioannis Pauli II, decrevit Pontificiam Academiam Cracoviensem ad Pontificiam Universitatem Crecoviensem Ioanni Pauli II dicatam ad disciplinas ecclesiasticas colenadas promovere...” The whole Latin version of the "Letter” (no. 1344/2005), see: „Analecta Cracoviensia” 41(2009), p. 3. 
(1979) and in the regulations attached to it (currently in the constitution Veritatis gaudium [2017] and in the attached regulations). ${ }^{8}$

Both the above-mentioned "development of the ecclesiastical sciences" and "the service of thought" are implemented through systematic lectures, as well as by international scientific conferences, symposia and other scientific activities. Therefore in this paper hereafter will be taken in consideration the most important events which occurred during last ten years of the activity of our University. ${ }^{9}$

\section{The Cyclic Events}

Four important events that occur regularly every year will first be discussed: the solemn inauguration of the academic year, the Days of John Paul II, the Tischner Days and International Conference: The Role of the Catholic Church in the Process of European Integration.

There is a long tradition to start every new academic year with a pilgrimage to a sanctuary near Krakow. First we made pilgrimages to the Marian Sanctuary in Kalwaria Zebrzydowska (on last working day of September), however more recently they are done to the Sanctuary of St. John Paul II in Krakow in the so-called White Seas. The schedule of the pilgrimage is the same every year: a reflection on a selected topic held by a professor, than the concelebrated Mass with a homily held by a representative of one of the major seminaries collaborating with the Faulty of Theology. After a lunch break, a rosary is prayed in the rosary garden by the shrine; it is prepared by seminarians who are also students of theology enrolled at our university's Faculty of Theology. The pilgrimage is attended by professors, staff, librarians, and students (seminarians studying in Krakow's diocesan and regular seminaries, nuns, and lay students) from our University. During the pilgrimage, we pray for God's blessings for the whole university community in the new academic year.

The official inauguration of each new academic year is celebrated in a very solemn manner. The date of the celebration refers to the date of the election

${ }^{8}$ Cf. Statut Uniwersytetu Papieskiego Jana Pawła II w Krakowie [Statute of the Pontifical University of John Paul II in Krakow], Kraków 2015, p. 3s (\$2).

${ }^{9}$ The main source of the information hereafter reported is a set of articles under commune title "Chronica" published in "Analecta Cracoviensia" 42(2010) - 50(2018). So, hereafter those articles will be quoted as Chronica 42 (1010)... Their exact list is in the Bibliography attached to this paper. 
of St. John Paul II to the Holy See (October 16, 1978). The inauguration ceremony usually consists of two parts: the liturgical one in the collegiate church of St. Anna and the academic part in the Krakow Philharmonic Hall. The solemn inaugural Mass is presided over by a bishop invited by our Grand Chancellor Cardinal Stanisław Dziwisz (the most recent one by Abp Marek Jędraszewski). The homily is delivered by another invited bishop or professor. After the Mass, the participants of the inauguration ceremony walk in a solemn procession to the Krakow Philharmonic Hall, where after singing Gaude Mater Polonia the Rector of the University makes a speech, welcoming the guests, among whom are: the bishops from Krakow and other polish dioceses, the representatives of secular authorities, members of parliament, and diplomats, the representatives of Polish universities and others guests. Many others important persons invited to the ceremony send telegrams and letters of congratulations: among them members of the bishops' conference and representatives of Polish universities and secular authorities. In 2009 the Holy Father Benedict XVI, Cardinal Zenon Grocholewski (Prefect of the Congregation for Catholic Education), Archbishop Józef Kowalczyk (Apostolic Nuncio in Poland), Archbishop Józef Michalik (Chairman of the Conference of the Polish Episcopate), Mr. Lech Kaczyński (President of the Republic of Poland), Mr. Bronisław Komorowski (Speaker of the Parliament of the Republic of Poland), Mr. Prof. Dr. Hab. Wiesław Banyś (Chairman of the Conference of Rectors of Polish Universities) and many well-known public and Church personages sent their congratulation letters and telegrams for that outstanding inauguration ceremony. ${ }^{10}$ In 2010, among others, Archbishop Józef Kowalczyk (the Primate of Poland), Cardinal Józef Glemp (Senior Primate), Archbishop Józef Michalik (Chairman of the Conference of the Polish Episcopate), Cardinal Marian Jaworski, Archbishop Kazimierz Nycz (Metropolitan of Warsaw), Archbishop Józef Życiński (Metropolitan of Lublin) sent their letters of congratulations and telegrams for the inauguration ceremony. ${ }^{11}$ In 2011 the congratulation letters and telegrams were sent by: Archbishop Józef Kowalczyk (Polish Primate), Archbishop Józef Michalik (President of the Polish Bishops' Conference), Archbishop Celestino Migliore (Apostolic Nuncio), Cardinal Zenon Grocholewski (Prefect of the Congregation for Catholic Education), Bishop Prof. Andrzej F. Dziuba (Bishop of Łowicz and Chairman of the Scientific Council of the Polish Episcopal Conference), Bishop

\footnotetext{
${ }^{10}$ Chronica 42(2010), p. 434.

${ }^{11}$ Chronica 43 (2011), p. 406s.
} 
Józef Guzdek (Bishop for the Military Services), Mr. Prof. Wiesław Banyś (Rector of the University of Silesia in Katowice and President of the Conference of Rectors of Polish Universities). ${ }^{12}$ In 2012 the telegrams and congratulatory letters were sent by: Archbishop Józef Kowalczyk (Primate of Poland), Archbishop Józef Michalik (President of the Polish Episcopal Conference), Archbishop Celestino Migliore (Apostolic nuncio to Poland), Cardinal Stanisław Nagy SCJ, Archbishop Henryk Hoser SAC (Archbishop of Warsaw-Praga), Bishop Prof. Andrzej Dziuba (Bishop of Łowicz and Chairman of the Scientific Council of the Polish Episcopal Conference) and other bishops as well as the rectors of the state universities. ${ }^{13}$ In 2013 the congratulatory telegrams and letters were sent by: Bishop Prof. Dr. Hab. Andrzej F. Dziuba (Bishop of Łowicz and Chairman of the Scientific Council of the Polish Episcopal Conference), Rev. Dr. Piotr Bajor (Secretary of the Congregation for Catholic Education), Mr. Bronisław Komorowski (President of the Republic of Poland), Mrs. Prof. Barbara Kudrycka (Minister of Science and Higher Education of the Republic of Poland), Mr. Prof. Dr. Hab. Wiesław Banyś (Chairman of the Conference of Polish Academic Schools) and others bishops, representatives of Polish universities and secular authorities. ${ }^{14}$ In 2014 Mr. Bronisław Komorowski (President of the Republic of Poland), Mrs. Prof. Lena Kolarska-Bobińska (Minister of Science and Higher Education), Cardinal Kazimierz Nycz (Archbishop of Warsaw), Archbishop Wojciech Polak (Archbishop of the Roman Catholic Diocese of Gniezno and Primate of Poland), Archbishop Celestino Migliore (Papal Nuncio in Poland), Archbishop Jan Babjak, SJ (Archbishop of Prešov and Metropolitan Archeparch of the Ukrainian Greek Catholic Church in Slovakia) and many others important persons sent telegrams and congratulatory letters for the inaugural ceremony. ${ }^{15}$ In 2015 Mr. Andrzej Duda (President of Poland), Mr. Marek Sowa (Marshal of the Lesser Poland Region), Cardinal Zenon Grocholewski (former Prefect of the Congregation for Catholic Education), Archbishop Wojciech Polak (Archbishop of Gniezno and Primate of Poland), Archbishop Jan Babjak, SJ (Archbishop of Prešov and Metropolitan of the Greek-Catholic Church in Slovakia), Bishop Prof. Dr. Hab. Andrzej F. Dziuba (Bishop of Lowicz and Chairman of the Academic Council of the Polish Bishops'

\footnotetext{
2 Chronica 44 (2012), p. 325.

3 Chronica 45 (2013), p. 357.

${ }^{14}$ Chronica 46 (2014), p. 321s.

${ }^{15}$ Chronica 47 (2015), p. 258 s.
} 
Conference), Bishop Artur G. Miziński (Secretary General of the Polish Bishops' Conference), Bishop Józef Guzdek (Bishop of the Military Ordinariate of Poland), Mr. Prof. Dr. Hab. Wiesław Banyś (Rector of the University of Silesia in Katowice and Chairman of the Conference of Rectors of Academic Schools in Poland) are the most important people who sent their telegrams and congratulatory letters. ${ }^{16}$ In 2016 such letters and telegrams were sent, among others by: Mr. Andrzej Duda (President of Poland), Mr. Jarosław Gowin (Deputy Prime Minister of Poland and Minister of Science and Higher Education), Mr. Prof. Dr. Hab. Engineer Maciej Chorowski (Director of the National Center for Research and Development), Mr. Prof. Dr. Hab. Kazimierz Wiatr (Marshal of the Lesser Poland Region), Archbishop Wojciech Polak (Archbishop of Gniezno and Primate of Poland), Archbishop Stanisław Gądecki (Archbishop of Poznan and President of the Polish Bishops' Conference).$^{17}$ In 2017 telegrams and congratulatory letters sent: Mr. Andrzej Duda (President of Poland), Cardinal Zenon Grocholewski (former Prefect of the Congregation for Catholic Education), Cardinal Tarcisio Bertone (former Secretary of State of the Holy See), Archbishop Stanisław Gądecki (Archbishop of Poznan, President of the Polish Episcopal Conference and Deputy President of the Council of the Bishops' Conferences of Europe), Archbishop Wojciech Polak (Archbishop of Gniezno and Primate of Poland), Rev. Piotr Bajor (Secretary of the Congregation for Catholic Education), Mr. Jacek Krupa (Marshal of the Lesser Poland Region).$^{18}$ Finally, in 2018 Mr. Andrzej Duda (President of Poland), Mr. Władysław Kosiniak Kamysz (Leader of Polish People's Party), Cardinal Kazimierz Nycz (Metropolitan of Warsaw), Archbishop Grzegorz Ryś (Metropolitan of Łódź), Bishop Józef Guzdek (Bishop of the Military Ordinariate of Poland), Rev. Prof. dr drh.c. Wendelin Knoch (Professor emeritus of Ruhr-University of Bochum, Germany), Rev. Piotr Bajor (Secretary of the Congregation for Catholic Education) and many others important persons sent their telegrams and congratulatory letters. ${ }^{19}$ All those letters and telegrams expressed appreciation for our pontifical university and wishes of further dynamic development. In the next part of the inauguration speech, His Magnificence Rector recalls the most important

${ }^{16}$ Chronica 48 (2016), p. 405s.

${ }^{17}$ Chronica 49 (2017), p. 396s.

${ }^{18}$ Chronica 50 (2018), p. 309s.

${ }^{19}$ Cf. http://upjp2.edu.pl/uczelnia/x-uroczysta-inauguracja-roku-akademickiego-20182019upjpii (August 23, 2019). 
achievements in the previous academic year, e.g. opening of a new field of studies or a start-up of a new scientific project. At the end of his speech, the rector says thank to all the staff members for their efforts on behalf of the university, especially to those who in some way contributed to its promotion in the academic milieu and to its development, and thus to the professors and other didactic and research staff, library employees, the university administration, and also to the Psalmodia Choir.

The next part of the inauguration ceremony is the matriculation of first-year students at the university's four faculties (Theology, Philosophy, History and Cultural Heritage, and Social Sciences). In this ceremony only the representatives of each group of the students usually take part. The matriculation act consists in the act of His Magnificence Rector, touching the student's shoulder with his scepter (the accolade to the studenthood) and in handing over the student's book. At end of this ceremony the president of the Students' Union, always gives a speech in which he encourages his new classmates to make the best use of the opportunities offered by our University and to become engaged in the work of the Students' Union.

After the matriculation, awards and distinctions are presented: the state distinctions (by the president of Poland, by the minister of national education) and the university distinctions (by His Magnificence Rector). The state awards are presented on the basis of Article 138 of the Constitution of the Republic of Poland and the law on orders and distinctions for the exemplary and particularly conscientious exercising of one's professional duties. The rector's awards are presented for achievements in research, teaching, and organizational work, and also for the best dissertations and M. A. thesis.

The final point of the inauguration ceremony usually is the inaugural lecture. However, sometimes there is a ceremony of the bestowing of an honorary ( $h o-$ noris causa) doctorate which concludes with the lecture called lectio magistralis. Thus in 2009 the inaugural lecture on "Cardinal Karol Wojtyła: The church itself is to constitute its teaching. Idea and implementation" was delivered by the first rector of the Pontifical Academy of Theology in Krakow cardinal and professor Marian Jaworski, who recalled K. Wojtyla's point of view on catholic education. ${ }^{20}$ In 2010 it was delivered by professor Antoni Jackowski from the Jagiellonian University and its topic was "Man on a pilgrimage." ${ }^{21}$ In 2011 the inaugural lecture

\footnotetext{
${ }^{20}$ Chronica 42 (2010), p. 435.

${ }^{21}$ Chronica 43 (2011), p. 407.
} 
on "Education for Freedom" was delivered by Prof. Mirosław Handke from the AGH University of Science and Technology in Krakow ${ }^{22}$. In 2012 the inaugural lecture dedicated to "The Logos-Based Nature of the Faith of Joseph Ratzinger/ Benedict XVI” was given by Rev. Prof. Krzysztof Góźdź from the John Paul II Catholic University of Lublin. ${ }^{23}$ In the next year (2013) the inaugural lecture entitled "Ethics and Politics" was given by Archbishop Jean-Louis Bruguès, Archivist and Librarian of the Holy Roman Church and former Secretary of the Congregation for Catholic Education. ${ }^{24}$ In 2014 the inaugural lecture entitled "The Service of Thinking and Gaudium Veritatis" was given by Rev. Prof. Józef Makselon from the Faculty of Philosophy of our University. ${ }^{25}$ In 2015 there was the h. c. doctorate bestowed to the archbishop Celestino Migliore, who since 2010 was the apostolic nuncio in Poland.$^{26}$ In 2016 the inaugural lecture entitled "Important Words and the Most Important Words" was given by Mr. Prof. Dr. Hab. Walery Pisarek. ${ }^{27}$ In 2017 it was the honorary doctorate bestowed to Cardinal Gerhard Ludwig Müller, who for many years served as the Bishop of Regensburg (2002-2012) and later, until 2017, as the Prefect of the Vatican Congregation for the Doctrine of the Faith. ${ }^{28}$ Finely, in 2018, the inaugural lecture entitled "The Pontificate for the Church and the World" was delivered by Card. Stanisław Dziwisz, former Great Chancellor of our University. ${ }^{29}$ Each year the entire inauguration ceremony is graced by the singing of the "Psalmodia" Choir of the Pontifical University of John Paul II directed by Mr. Włodzimierz Siedlik..$^{30}$

${ }^{22}$ Chronica 44 (2012), p. 326.

${ }^{23}$ Chronica 45 (2013), p. 358.

${ }^{24}$ Chronica 46 (2014), p. 322.

${ }^{25}$ Chronica 47 (2015), p. 260

${ }^{26}$ More information on the Archbishop C. Migliore's honorary doctorate, see: Promotio doctoris honoris causa Pontificiae Universitatis Cracoviensis Ioannis Pauli II. Reverendissima Excellentia Caelestinus Migliore, ed. M. Wiertek, Kraków: Uniwersytet Papieski Jana Pawła II 2015, pp. 74.

${ }^{27}$ Chronica 49 (2017), p. 398.

${ }^{28}$ More information on the Cardinal G. Müller's honorary doctorate, see: Promotio doctoris honoris causa Pontificiae Universitatis Cracoviensis Ioannis Pauli II. Eminentissimus professor cardinalis Gerhard Ludwig Müller, ed. M. Mastyło, Kraków: Uniwersytet Papieski Jana Pawła II 2017, pp. 186.

${ }^{29}$ M. Mastyło, Inauguracja roku akademickiego 2018/2019 [The inauguration of the academic year 2018/2019 (in Polish)] "Vita Academica" 96/3 (2018), p. 8.

${ }^{30}$ More details on the inauguration ceremonies in the ten past years, see: Chronica 42 (2010), p. 433-435; 43 (2011), p. 406-408; 44 (2012), p. 324-326; 45 (2013), p. 355-358; 46 (2014), 
Another important cyclical event in the past ten years were the Days of John Paul II, which are regularly held each year and are organized by universities represented in the Krakow College of University Rectors. They are of an academic, interdisciplinary, popular, and cultural nature and are the inspiration for academic research and the popularization of John Paul II's teaching. They take place every year at the beginning of November (because of the feast of St. Charles Borromeo, John Paul II's patron saint, and the anniversary of his ordination). In 2018 there was their thirteenth edition. Throughout the reported period, the Days of John Paul II were held at the campuses of several universities belonging to the aforementioned College. The honorary patrons of the Days were: the Archbishop of Krakow, the Voivode of Lesser Poland; the Marshal of the Lesser Poland Region; and the Mayor of Krakow. Such a patronage means the engagement also of the civil authorities. The first edition of the Days was in 2006.

Each edition of the Days was dedicated to a different leading idea which served as key for the interpretation of the pope's teaching and was the main theme of the conferences, competitions and homilies. The schedule of each edition was the following: a press conference of the event's organizers, an academic sessions and symposiums, cultural events like theatrical performances, concerts and exhibits of photographs, a literary and photographic contests for students from across Poland for works inspired by the teaching of Karol Wojtyła/John Paul II. The results of the contests are announced after the Holy Mass concluding the Days and then prizes are awarded to the winners. The main event of the Days is the scientific symposium, which takes place in the Auditorium of Collegium Novum of the Jagiellonian University and is organized by the Jagiellonian University as well as our University.

The leading ideas (the topics) of the ten latest editions of the Days of John Paul II were as follows: "Faith and science" (2009), "Freedom" (2010), "The Dignity" (2011), "Dialogue" (2012), "The Wisdom" (2013), "Hope" (2014), "Holiness" (2015), "Mercy" (2016), "Human rights and the rights of peoples" (2017), "The Independence" (2018). ${ }^{31}$ Studying this topics our University with whole Krakow

p. 319-322; 47 (2015), p. 256-260; 48 (2016), p. 403-408; 49 (2017), p. 394-398; 50 (2018), p. 308-314; M. Mastyło, Inauguracja roku akademickiego 2018/2019 [The inauguration of the academic year 2018/2019 (in Polish)] "Vita Academica" 96/3 (2018), p. 5-15.

${ }^{31}$ Chronica, 42 (2010), p. 436n.; 43 (2011), p. 408; 44 (2012), p. 326n.; 45 (2013), p. 358n.; 46 (2014), p. 323n.; 47 (2015), p. 260-262; 48 (2016), p. 408-410; 49 (2017), p. 398-400; 50 (2018), p. 314-316. 
academic milieu continues and evolves "the service of thought" according to the teaching of Pope John Paul II.

The other significant and Krakow distinctive feature are the Tischner Days. Rev. Prof. Józef Tischner (1931-2000), a philosopher known across Poland and Europe, also had a major impact on the intellectual milieu of not only Krakow, but on that across Poland, especially in the times of "Solidarność" (Solidarity). A form of popularizing his philosophical and political-social thought are just the Tischner Days. The first Days were organized in 2001 and in 2019 we had their nineteenth edition. The days are organized by our University, the National Academy of Theatre Arts in Krakow, the Jagiellonian University, the Znak Social Publishing Institute, and the Józef Tischner Institute. The event's honorary patron was Cardinal Stanisław Dziwisz and now is Archbishop Marek Jędraszewski.

The topics of the ten latest editions of the Tischner Days were as follows: "Faith in the Hour of Turn" (2010), "Patriotism" (2011), "The Meeting" (2012), "Looking for Hope" (2013), "The Courage to Think" (2014), "The Dispute About Man” (2015), "Roads to Freedom" (2016), “Others/Foreigners/Neighbors” (2017), "Freedom and the Word" (2018), "Man. New challenges" (2019). ${ }^{32}$

The fourth of the mentioned cyclic events is the International Conference: "The Role of the Catholic Church in the Process of European Integration". During the reported period it was held in the second half of September. But later, in the academic year 2017/2018 it took place in the second half of October instead. Along with the change of date, the location of the meeting was also ("experimentally") changed from Tomaszowice outside Krakow to the very heart of the royal city, to the International Cultural Center of the Main Market Square. The aim of this change was to make it possible for the youngest academic staff, students, and all those engaged in the popularization of European integration not only in Poland, but also abroad, especially in Central and Eastern Europe, to participate in this debate.

The conference is organized by our University in cooperation with the Konrad Adenauer Foundation and the Robert Schuman Foundation in Luxembourg. The organization's partners also included the European People's Party (Christian Democrats) in the European Parliament, The Commission of the Bishops' Conferences of the European Community (COMECE - lat. Commissio Episcopatuum Communitatis Europaeae) in Brussels, and the "Wokół nas"

${ }^{32}$ Chronica, 42 (2010), p. 440; 43 (2011), p. 413 n.; 44 (2012), p. 332; 45 (2013), p. 360; 46 (2014), p. 325; 47 (2015), p. 263n.; 48 (2016), p. 411 n.; 49 (2017), p. 401 n.; 50 (2018), p. 319. 
publisher in Gliwice. From the beginning (since 2001), the chairman of the Organizing Committee was Bishop Prof. Tadeusz Pieronek, former rector of our University. Usually there are more than 300 persons, including more than thirty from countries encompassed by the European Union's Eastern Partnership Program (especially Ukraine, Georgia, Belarus, and Armenia) participate each year in this conference.

The schedule of the conference consists of three panel sessions during the first day. On the evening of this first day, the conference participants have the opportunity to participate in a Mass in a church in the Old City of Krakow. On the second day, only one panel session takes place in the morning. Each panel session has its own topic. The conference ends with lunch on the second day. A total of twenty lecturers and experts as well as four moderators is usually involved. Each edition of this conference is focused on a specific topic. So, its ten last editions was dedicated to: "The Christian responsibility in a face of crisis" (2009), "The Christians' Contribution to the European Integration Process" (2010), "The ethical dimension of politics" (2011), "Christian expectations regarding the shape of Europe" (2012), "Family in Contemporary Europe" (2013), "What unites and divides us in Europe?" (2014), "Dignity - Freedom Human Rights" (2015), "European Solidarity" (2016), "Where is Europe heading towards?" (2017), ${ }^{33}$ "Perspectives for the Development of the European Union" (2018). ${ }^{34}$ The edition of 2019 will be dedicated to "Challenges for a new Europe"35 and it will be its first edition without Bishop Tadeusz Pieronek who passed away on December 27, 2018. Among the most important speakers were such as, for example: Mr. Lech Wałęsa (Nobel Peace Prize laureate, former President of Poland, 2009), Mr. Bronisław Komorowski (President of Poland, 2010,

${ }^{33}$ Chronica 42 (2010), p. 439; 43 (2011), p. 411 n.; 44 (2012), p. 330n.; 45 (2013), p. 365n.; 46 (2014), p. 331; 47 (2015), p. 271-273; 48 (2016), p. 423-425; 50 (2018), p. 331-333. Cf. International Conference. The Role of the Catholic Church in the Process of European Integration. Review of Events. Cracow 2001-2017, eds. R. Budnik, M. Góra, Gliwice: Wydawnictwo „Wokół nas" 2018, pp. 76 (ISBN 978-83-88199-73-8).

${ }^{34}$ Perspectives for the Development of the European Union. The Role of the Catholic Church in the Process of European Integration, eds. M. Chudzio, R. Budnik, M. Góra, Gliwice: The "Wokół nas" Publishing House 2019, pp. 222 (On line version: http://www.kosciol-europa.org. pl/wp-content/uploads/krakow2018-EN.pdf (1.08.2019).

${ }^{35}$ More details (in polish): http://www.kosciol-europa.org.pl/ (1.08.2019). See also: http://www.upjp2.edu.pl/sites/default/files/materialy/broszura\%20konferencyjna\%2020012017\%282\%29\%281\%29.pdf (August 26, 2019); International Conference. The Role of the Catholic Church..., p. 30-65. 
2011, 2013), Mr. Hans-Gert Poettering (Chairman of the Konrad Adenauer Foundation, 2010, 2011, 2016), Abp. Celestino Migliore (Apostolic Nuncio to Poland, 2011, 2013, 2015), Mr. Jacek Saryusz-Wolski (MEP, chairman of the PO-PSL club in the EPP, 2011, 2015), Mr. Prof. Joaquin Navarro-Valls (former Vatican spokesperson, 2011), Msgr. Ettore Balestrero (Undersecretary of State for Relations with States of the Holy See, 2011), Mr. Jacques Santer (former President of the European Commission), Mr. Rocco Buttiglione (Italian Parliament vice president, 2012, 2015), Mr. Krzysztof Zanussi (famous Polish film and theatre director, 2012), Card. Kazimierz Nycz (Metropolitan of Warsaw, 2012), Archbishop Jean-Claude Hollerich (Bishop of Luxembourg, 2012), Mrs. Prof. Marguerite Peeters (Institute for Intercultural Dialogue Dynamics of Brussels, 2013), Mrs. Prof. Inga Iwasiów (Institute of Polish Studies and Cultural Studies of University in Szczecin, 2013), Archbishop Henryk Hoser (Bishop of Warszawa-Praga, 2013), Mr. Gyorgi Holvenyi (State Secretary in the Ministry of Social, Cultural and Educational Affairs in Hungary, 2013), Mrs. Ria Oomen-Ruijten (Dutch MEPs from the EPP Group, 2013, 2017), Bishop Tadeusz Szuman (bishop of the evangelical diocese of Katowice, 2013), Archbishop Francesco Montenegro (Bishop of Agrigento, 2014), Mrs. Flaminia Giovaneli (Undersecretary in the Papal Commission Iustitia et Pax, 2014), Mr. Dr. Cezary Koscielniak (Adam Mickiewicz University in Poznan, 2014), Fr. Syed Hilal S.J. (Jesuits' Refugees Centre in Homs, Syria, 2014), Mr. Horst Langes (Honorary Chairman of the Robert Schuman Foundation in Luxembourg, 2014, 2016), Mr. Prof. Adam D. Rotfeld (Institute of Political Studies at the Polish Academy of Sciences, 2014), Mr. Jean-Claude Juncker (President of the European Commission, 2015), Abp. Dr Silvano Tomasi (Pontifical Council Iustitia et Pax, 2016), Mr. Prof. Jerzy Buzek (Member of EP, 2016), Abp. dr Salvatore Pennacchio (Apostolic Nuncio to Poland, 2017), Mr. Dr. Janusz Lewandowski (Member of the European Parliament, 2017), Bishop Rimantas Norvila (Chairman of the COMECE Commission for International Cooperation with EU, 2018), ${ }^{36}$ Mr. Antonio Tajani (President of the European Parliament, 2017, 2018) and Mr. Donald Tusk (President of the European Council, 2018). ${ }^{37}$

\footnotetext{
${ }^{36}$ Cf. International Conference. The Role of the Catholic Church..., p. 30-65.

${ }^{37}$ http://www.upjp2.edu.pl/konferencje-sesje/perspektywy-rozwoju-unii-europejskiej\%E2\%80\%93-xviii-mi\%C4\%99dzynarodowa-konferencja-rola (August 26, 2019).
} 


\section{Scientific Conferences}

The other manner of carrying out "the service of thought" are the scientific symposia and conferences organized by different units of our University (like Faculties, Institutes or Chairs). Such scientific events serve to increase knowledge transmitted during regular didactic classes and stimulate research in different fields of theological and humanistic knowledge. At the same time they create the right space to discuss and to popularize the results of research undertaken by various academic-didactic staff from our University. Every year, dozens of such events were organized, some of them in cooperation with domestic and foreign scientific institutions. Many papers which were presented during such events were then published in different scientific publications (periodicals and books). In total, ca. 450 events have been organized over the last 10 years. ${ }^{38}$ Due to limits of this paper only the most important ones will be mentioned here, especially those that take place regularly.

Special attention should be paid first to the international conferences. One of the major challenges for philosophers of nature and even for theologians is the interpretation of the results of the research of contemporary physics, especially cosmology. It is obvious that methodology is here crucial. Hence our Faculty of Philosophy together with the Polish Academy of Learning, the Copernicus Center in Krakow, and the John Templeton Foundation organize the annual "Krakow Methodological Conference" (this started since 1992/1993, however at the beginning they were different meetings on "Universe and Mathematics"). The last one was in November 2019. A special guest of this conference was Rev. Prof. Michał Heller, a cosmologist and theologian and laureate of the Templeton Prize (2008). The titles of the last ten editions of the conference were: "Road to Reality with Roger Penrose" (May 20-21, 2010), "The Emotional Brain" (May 19-20, 2011), "The Causal Universe" (May 17-18, 2012), "The Normative Mind: Dimensions of Decision-Making” (May 16-17, 2013), “The Limits of Physics and Cosmology" (May 8-9, 2014), "One Hundred Years of General Relativity Theory" (May 26-27, 2015), "Philosophy in Science" (May 30-31, 2016), "On What Exists in Physics" (October 5-6, 2017), "Emergence of the

${ }^{38}$ This number results from archives information on conferences and sessions, cf. http:// www.upjp2.edu.pl/konferencje_sesje_archiwum (27.08.2019) and from the journal "Vita Academica" 51/52(2009) - 96(2018), section "Wydarzyło się" (It happened). 
Classical" (October 11-12, 2018) ${ }^{39}$, "Is Logic a Physical Variable?" (November $7-9,2019) .^{40}$ Such conferences are of great importance, because they provide criteria for correct and creative thinking which is fundamental to "the service of thought".

Ethics is of great importance in the life of every community of people, both religious and secular, because it defines interpersonal relationships, which often are exposed to different risks. To counter these risks the Chair in Ethics and the Chair in Social and Political Philosophy at the Faculty of Philosophy organize academic conferences in the series entitled (since 2008): "Ethics and Public Life". In previous editions, the following topics were dealt with: "A Lie and the Public Life" (October 21-22, 2009), "Authenticity and Public Life" (October 19-20, 2010), "Equality and Public Life" (October 25-26, 2011), "Faces of greed and Public Life" (October 23-24, 2012), "Trust and Public Life" (October 29-30, 2013), "Hatred and Public Life" (October 27-28, 2014), "Indifference and Sensitivity in Public Life" (October 27-28, 2015), "Honesty and Sincerity in Public Life" (October 25-26, 2016), "The Law and Morality in Public Life" (October 24-25, 2017). The topic of the last (nineteenth) conference was: "Justice in Public Life" (October 29-30, 2018). ${ }^{41}$

In the post-modern world, which seems to be dispose of a deeper spirituality, the popularization of the spirituality of religious orders and the emphasis of the spiritual legacy of its masters takes on a special meaning. It is a task undertaken by a series of National Academic Conferences on "The Spirituality of Polish Monasteries: Message and Communication” (since 2009). The conferences are organized by our University as well as the religious congregation of which the elected master of spirituality was a member. The last ten were dedicated to the following religious orders or their spiritual leaders: "Pray and Work: Cistercians Shape Themselves and the World" (December 4, 2009), "The Servant of God: Fr. Peter Semenenko, CR and the Resurrectionist School of Spirituality (March 15, 2011), "Fr. Hieronim Kajsiewicz CR (1812-1873): Concern for Spirituality as the Care for the Welfare of the Community" (February 28, 2012), "Infatuated with

\footnotetext{
${ }^{39} \mathrm{http}: / /$ www.copernicuscenter.edu.pl/en/conferences/ (August 29, 2019).

${ }^{40}$ https://www.copernicuscenter.edu.pl/conference/23-krakowska-konferencjametodologiczna-czy-logika-jest-zmienna-fizyczna/ (only in Polish, February 28, 2020).

${ }^{41}$ Chronica 42 (2010), p. 442; 43 (2011), p. 415; 44 (2012), p. 334; 45 (2013), p. 369; 46 (2014), p. $335 ; 47$ (2015), p. 281 s.; 48 (2016), p. $428 ; 49$ (2017), p. 416 s.; 50 (2018), p. 339s.; cf. http:// wf.upjp2.edu.pl/sites/default/files/Sprawiedliwo\%C5\%9B\%C4\%87\%20w\%20\%C5\%BCyciu\%20 publicznym\%20-\%20program.pdf (August 30, 2019).
} 
God and Attentive to Man: St. Angela Merici and Her Work Realized by the Polish Ursuline Sisters of the Roman Union" (February 9, 2013), “The Mission of Bulgarian Resurrectionists: One Hundred and Fifty Years in Service to the Church and Society" (February 19 2013), "Concerning Piotr Semenenko's Diary" (March 12, 2014), "St. Urszula Ledóchowska: A Woman in the Church and in Society" (April 17, 2015), "Rev. Stefan Pawlicki, CR: A Man of Faith and Science in the Service of Social and Religious Renewal" (February 17, 2016), "Celina and Jadwiga Borzęcka: The Spiritual Inspirations and Social Activity of Mother and Daughter" (October 29, 2016, [Kęty, about 75 kilometers southwest from Krakow]), "Rev. Paweł Smolikowski, CR: A Life for God, the Church, and Society" (February 21, 2018). ${ }^{42}$ The last one, was also dedicated to spirituality of the Resurrectionist Congregation: "Resurrectionists and the Rebirth of the Homeland" (March 13, 2019). ${ }^{43}$

The above mentioned importance of ethics applies particularly to the mass media. Truth and honesty are the most fundamental values that are the criterion for its evaluation and allow us to distinguish between true and false ones. Our scientists have been discussing for thirteen years during scientific conferences organized under the common title "Media Ethics" how these values function in the modern media world. This series of conferences is organized (since 2006) by the Institute of Journalism and Social Communication of our University as well as the Polish Communication Association. The topics of the last ten conferences were: "Good in the Media - Good of the Media" (May 13-14, 2010), "Responsibility in mass media - responsibility of mass media" (May 19-20, 2011), "Values in the media - media value" (May 31-June 1, 2012), "Understanding the Media: Wisdom in the Media?" (May 16-17, 2013), "Privacy in the Media: Private and Social Media" (May 13-14, 2015), "Media Ethics: Ethicality in the Media" (May 18-19, 2016), "Trust in the Media, Confidence in the Media" (May 24-25, 2017), "Truthful Media: Honesty and the Truth in the Media" (May 24-25, 2018), "Dignity in the Media - the Media Worthy Person" (May 22-23, 2019). ${ }^{45}$

${ }^{42}$ Chronica 42 (2010), p. 448; 43 (2011), p. 419; 44 (2012), p. 338; 45 (2013), p. 373; 46 (2014), p. $341 ; 47$ (2015), p. 290; 48 (2016), p. 435; 49 (2017), p. 417; 50 (2018), p. 349.

${ }^{43}$ http://upjp2.edu.pl/konferencje-sesje/zmartwychwsta\%C5\%84cy-i-odrodzenieojczyzny-\%E2\%80\%93-xvii-og\%C3\%B3lnopolska-konferencja-naukowa-z (August 30, 2019).

${ }^{44}$ Chronica 42 (2010), p. 451; 43 (2011), p. 421; 44 (2012), p. 341; 45 (2013), p. 373; 46 (2014), p. 343 s.; 47 (2015), p. 294s.; 48 (2016), p. 443 s.; 49 (2017), p. 426 s.; 50 (2018), p. 357.

${ }^{45}$ http://www.upjp2.edu.pl/konferencje-sesje/xiii-konferencja-naukowa-etykimedi\%C3\%B3w-22-\%E2\%80\%93-23-v-2019 (August 30, 2019). 
The study of Russian philosophical thinking helps to better understand the history, culture and politics of our big neighbor - Russia. Since 2010 a series of scientific and international conferences are organized by our university's Department of the Philosophy of Religion, and for several years in the collaboration with the Edith Stein Institute in Granada (Spain), as well as the Center for the Study of the Christian Orient in Granada (Spain). Their common title is: "Krakow Meetings: Krakow Conferences on Russian Philosophy" and since 2016 they take place in the Benedictine Abbey in Tyniec outside Krakow. The conferences were devoted to the following topics: "Symbolism in Russian Culture" (May 13-14, 2010), "The Influence of Jewish Culture on the Central and Eastern European Culture" (June 2-3, 2011), "Metaphysics and Literature in Russian Culture in $19^{\text {th }}$ and $20^{\text {th }}$ Century" (December 1-3, 2011), "Reception of Russian Thought in Europe" (June 27-28, 2013), "Religion and Culture in Russian Thought" (May 29-30, 2014), "Russian Religious Thought and Post-Secularism" (June 11-13, 2015), "Peter Chaadaev: Between the Love of Fatherland and the Love of Truth" (June 5-8, 2016), "Alexei Khomiakov: We Are Sobornost.' Integral Life in Slavophile Thought as an Answer to Modern Fragmentation. The Church, Empire and the Modern State" (May 28-31, 2017), "Eugene Trubetskoy: Icon and Philosophy" (June 3-6, 2018), "Vladimir Soloviev: The Metaphysics of Love" (June 2-5, 2019). ${ }^{46}$

In addition to regularly organized scientific conferences there were also many individual ones devoted to topics considered important at a given time. The following are but some of those worth mentioning.

The fiftieth anniversary of the ratification of the Second Vatican Council's constitution about the liturgy, Sacrosanctum Concilium, which inaugurated the renewal of the Church's liturgical life, was an occasion for organizing an international meeting of liturgical theologians as part of the "Ad fontes liturgicos" series. It was titled: "Liturgical Reforms and the Return to the Sources". The symposium took place on October 23-24, 2013 and was organized by the Liturgy Institute of the Pontifical University of John Paul II, the Greek-Catholic Theological Faculty in Prešov (Slovakia), the Ukrainian Catholic University and the Ukrainian Liturgical Center in Lviv (Ukraine). The symposium was devoted to studies on liturgical reforms in the Western Church and the Eastern Churches. ${ }^{47}$

\footnotetext{
${ }^{46}$ https://krakowmeetings.eu/conferences (August 30, 2019). Cf. Chronica 44(2012), p. 336s.; 46(2014), p. 344s.; 47(2015), p. 304-306; 48 (2016), p. 437s.; 49 (2017), p. 428-430; 50 (2018), p. 359.

${ }^{47}$ Chronica 46 (2014), p. 333s.
} 
In relation to the preparations for World Youth Day, an international academic symposium was organized. This symposium, entitled: "Are the Young the Hope of the Church, or Is the Church Hope for the Young?", took place at our University on April 13-16, 2016. It was organized by our Faculty of Theology's Institute of Practical Theology as well as by the Department of Pastoral Theology at the Johannes Gutenberg University of Mainz in Germany (Institut für Pastoraltheologie der Johannes Gutenberg-Universität in Mainz, Germany) in collaboration with Ruhr University Bohum (Ruhr Universität Bochum, Germany), the Greek-Catholic Faculty of Theology at the University of Prešov (Gréckokatolícka Teologická Fakulta Prešovskej Univerzity v Prešove, Slovakia), and the St. Józef Bilczewski Theological Institute in Lviv (Ukraine). It was devoted to the topics such as: the youth as seen by the Popes based on their speeches during world youth day; youth ministry in Germany; the concept of pluralism of religious pedagogy and its persistence with regards to new research on youth; Pope Francis' inspiration for youth ministry; youth unemployment as a social and ethical problem. ${ }^{48}$

The hundredth anniversary of the restoration of Polish independence (1918) presented a special occasion for academic research related to this great event for the Polish nation as well as for the Central Europe. The Catholic Church contributed to the struggle for the full sovereignty of Poland. In order to make them better known, the Department of Archival Studies and Auxiliary Historical Sciences of our University's Faculty of History and Cultural Heritage along with the Historical Section of the Polish Theological Society in Krakow organized a national academic conference titled: "The Paths to Independence and the Concern for Freedom in the Second Republic in Light of Church Archives". The conference took place on May 24-25, 2018. Its program consisted of eleven papers devoted to the different topics such as: the involvement of the Krakow clergy in the January Insurrection (1863-1864), the Legions in the struggle for independence, the activity of the Eastern Galician houses of the Felician Sisters in 1918-1920, the Brothers Hospitallers of Saint John of God in the Polish lands in 1918-1922, the patriotic education of the youth in Piarist schools, the activity of Dominican fathers in Poland after the regaining of independence. ${ }^{49}$

Half a century after the events of 1968 , known as the anthropological revolution, presented a unique occasion for studying the question of the causes, events,

${ }^{48}$ Chronica 48 (2016), p. 419-421.

${ }^{49}$ Chronica 50 (2018), p. 358 s. 
and consequences of this revolution. This revolution not only brought social and cultural changes, but also fundamentally changed the perception of man in general. The national academic conference entitled: "The Year 1968: Fifty Years after the Anthropological Revolution" was devoted to these topics. The conference took place on June 4-5, 2018. It was organized by the Chair in the Philosophy of Man at our University's Faculty of Philosophy. The topics discussed during the conference were related to four main phenomena of that revolution: the essence of the anthropological revolution of 1968; the reactions of Christian thinkers to this revolution; contemporary Christian thought and the legacy of 1968; and the ideas of that revolution present in contemporary philosophical anthropology. The conference program consisted of thirteen papers as well as a concluding discussion panel on the topic: "Fifty Years since the Anthropological Revolution". The conference showed the state of the discussion on anthropological questions from the perspective of the Christian thought of our times..$^{50}$

An important event of Catholic-Jewish dialogue was the first international scientific conference entitled "Traditions and customs of cultures and religions", which took place on April 11-12, 2019. It was organized by the Chair of Landscape and Cultural Heritage of our Faculty of History and Cultural Heritage, our Institute of Fundamental Theology, Ecumenism and Dialogue, then by Jewish Community Center and Toward Jerusalem Council II. The main topics of the conference were: celebration in Judaism, symbols hidden in the traditions and celebrations of Jewish holidays, festive everyday, Who are Messianic Jews? The messianic movement in a meeting with Christianity. ${ }^{51}$

The scientific events described above constitute a very small part of what has happened in the last ten years of our University's activity. As mentioned above, its main purpose is "the service of thought.".52

\footnotetext{
${ }^{50}$ Chronica 50 (2018), p. 361.

${ }^{51} \mathrm{http} / / /$ www.upjp2.edu.pl/konferencje-sesje/i-mi\%C4\%99dzynarodowa-konferencjanaukowa-tradycje-i-obyczaje-w-kulturach-i-religiach (August 31, 2019).

${ }^{52}$ More on the scientific symposia and conferences, see: Chronica 42 (2010), p. 441-453; 43 (2011), p. 414-423; 44 (2012), p. 333-342; 45 (2013), p. 368-380; 46 (2014), p. 333-347; 47 (2015), p. 275-310; 48 (2016), p. 426-449; 49 (2017), p. 415-436; 50 (2018), p. 335-365, "Vita Academica" 96/3 (2018), p. 33-48.
} 


\section{The Growth}

The promotion of our academic institution to a university was a powerful stimulator for its development. It is multidimensional: international cooperation, new structural units, new paths of studies, an increase in the number of academic staff and in the number of graduates and promoted students, enlarging the book collection and publications.

An important factor that leads to the flourishing of our University is the cooperation with international academic centers. Particularly vibrant is our contact with the academic milieu in Bochum at the Faculty of Catholic Theology of the Ruhr University Bochum (Germany), which has gone on uninterrupted since the signing of an agreement on November 6,1982 . The cooperation consists of mutual visits of students with professors. During such visits, they participate in symposia, visit the city and surroundings and meet colleagues. In recent years, meetings are held once a year in May in an alternating manner: one year German students come to Krakow, the next year our students go to Bochum. On the German side, Rev. Prof. Joachim Wiemeyer is responsible for its organization, while on the part of our University it is Rev. Dr. Hab. Jan Dziedzic. ${ }^{53}$

Similar cooperation agreements are in place with the universities in Ružomberok and Prešov (Slovakia), and Kyiv and Lviv (Ukraine). The continuous expansion of such international cooperation is attested to by the signing of new cooperation agreements every year. Usually those agreements encompass the exchange of academic didactic staff, students, academic publications, and the results of research, and also information in the field of didactics and the training of didactic staff, doctoral students, and undergraduates, advanced didactic materials, and the application of modern methods of teaching. So, in 2009, we had five bilateral agreements, whilst in 2018 there were a total of thirty-one agreements.

The bilateral agreements that were signed independent of the previous Erasmus exchange program, which now is called Erasmus+, are with the following: the Catholic University of the Sacred Heart (Milan, Italy), the Theological Faculty of Central Italy (Florence, Italy), the Salesian Pontifical University (Rome, Italy), the Theological-Philosophical Academy (Brixen/Bressanone, Italy), the University of Brescia (Brescia, Italy), the Pontifical University of Salamanca (Salamanca, Spain), Abat Oliba University (Barcelona, Spain), the University

${ }^{53}$ Chronica 50 (2018), p. 327. 
of Huelva (Huelva, Spain), the Faculty of Catholic Theology of Ruhr University (Bochum, Germany), the University of Würzburg (Würzburg, Germany), Brandenburg University of Technology Cottbus-Senftenberg (Cottbus, Germany), the Catholic Institute of Toulouse (Toulouse, France), the Catholic University of Croatia (Zagreb, Croatia), the University of Split (Split, Croatia), the University of Zagreb (Zagreb, Croatia), Pázmány Péter Catholic University (Budapest, Hungary), Ovidius University of Constantza (Constantza, Romania), SulkhanSaba Orbeliani Teaching University (Tbilisi, Georgia), Vytautas Magnus University (Kaunas, Lithuania), Constantine the Philosopher University in Nitra (Nitra, Slovakia), the University of Prešov (Prešov, Slovakia), the Catholic University in Ružomberok (Ružomberok, Slovakia), Ukrainian Catholic University (Lviv, Ukraine), the Thomas Aquinas Institute of Religious Studies in Kyiv (Kyiv, Ukraine), Zhytomyr Ivan Franko State University (Zhytomyr, Ukraine), the Lviv University of Trade and Economics (Lviv, Ukraine), the Russian Christian Academy for the Humanities (St. Petersburg, Russia), Dostoevsky Omsk State University (Omsk, Russia), Studium Theologicum Salesianum (Jerusalem, Israel), and the College of Specialist Pedagogical Preparation (Svatý Jan pod Skalou, Czech Republic)..$^{54}$

Our University participates in the EU program "Erasmus+", which is the main sphere of international cooperation (since December 2013, earlier LLP Erasmus) and which will last through the end of the 2020-2021 academic year. Every academic year, our University implements dozens of mobilities as part of the "Erasmus+" program. The development of this sphere of international cooperation show the following figures: in the 2009-2010 academic year we had seventeen such agreements, while in the 2017-2018 academic year we have one hundred and four of them. ${ }^{55}$

As for academic staff, in the academic year 2009-2010 there were 219 faculty members (35 professors, 56 associate professors and 111 doctors and 17 other persons) and 110 other employees (administration - 75, Library - 35) at our University. While in 2017-2018 academic year 431 persons were employed at our University (as of September 30, 2018). They were 273 academic staff, including: fifty-four titular professors, ninety-one habilitated doctors, ninety-seven doctors, thirty-one persons with Master of Arts degrees, and 158 remaining staff

\footnotetext{
${ }^{54}$ Chronica 50 (2018), p. 324.

${ }^{55}$ For the exact list of these agreements, see: Chronica 42 (2010), p. 438 and 50 (2018), p. 325-327.
} 
(105 employed in administration and twenty-seven in the library). Furthermore, six persons who are considered academic staff work in our library (in total, thirty-three persons work in our library). Twenty-six persons are employed in research and didactic projects. ${ }^{56}$

The unique sphere which lacks an evident growth is the number of students. In the 2009-2010 academic year, there were 3,318 undergraduates, doctoral students, and participants in post-graduate diploma studies, while in the 20172018 academic year 2,981 persons studied at our University. In the 2009-2010 academic year the number of students admitted for the first year of study was 839 (for cycles I, II and III), while in the 2017-2018 academic year - a total of 573 students were admitted to the first year of undergraduate and uniform M. A. studies. The decrease in the number of students results, among others, from a change in the way they are counted: some priest candidates from the affiliated seminaries are no longer considered to be our students. ${ }^{57}$

The number of degrees conferred in 2009-2010 academic year at our University included: 171 professional BA titles awarded upon concluding the I cycle of studies (Faculty of Philosophy - 26, Faculty of History and Cultural Heritage 37, Faculty of Social Sciences - 134), and 449 MA degrees awarded upon concluding the second cycle of study (Faculty of Theology - 295, Faculty of Philosophy 15, Faculty of History and Cultural Heritage - 20, Faculty of Social Sciences - 41, Faculty of Theology, Branch in Tarnow - 78), and 36 canon BA degrees (church, at the Faculty of Theology - 17, in Tarnow - 6). PhD degree was conferred on 26 people (at the Faculty of Theology - 19, the Faculty of Philosophy - 3, the Faculty of History and Cultural Heritage -4 ), a postdoctoral degree was awarded to 6 people and the Professor's title was bestowed on 2 persons.

Meanwhile the number of degrees conferred in 2017-2018 academic year included: 163 bachelor of arts degrees were granted at our University (thirteen at the Faculty of Theology, six at the Faculty of Philosophy, thirty-nine at the Faculty of History and Cultural Heritage, and 105 at the Faculty of Social Sciences), as were 375 master of arts degrees (194 at the Faculty of Theology, seventeen at the Faculty of Philosophy, seventeen at the Faculty of History and Cultural Heritage, 112 at the Faculty of Social Sciences, and thirty-five at the Faculty of Theology Theological Section in Tarnow) and sixty-seven licentiates in sacred theology (forty-six at the Faculty of Theology, fourteen at the Faculty of Canon Law, and

${ }^{56}$ Chronica 42 (2010), p. 454, Chronica 50 (2018), p. 370.

${ }^{57}$ Chronica 42 (2010), p. 454, Chronica 50 (2018), p. 370. 
seven at the Faculty of Theology - Theological Section in Tarnow). Thirty-five persons received doctoral degrees (eighteen at the Faculty of Theology, eight at the Faculty of Philosophy, four at the Faculty of History and Cultural Heritage, three at the Faculty of Social Sciences, and two at the Faculty of Theology - Theological Section in Tarnow), while four persons became habilitated doctors and five persons received the title of professor. ${ }^{58}$ In the period from 2009 to 2018 , the baccalaureate received were 1,769 , the master's degree 4,100 , the canonical licentiate 469 , doctorate -284 , habilitation (postdoctoral degree) -75 , professor's title -30 people.

The increase of employment, especially of academic staff (from 219 in 2010 to 273 in 2018), is due to the opening of many new study programs (new study paths) to attract new students. So, in the academic year 2018-2019 the University offered the following undergraduate and Master studies: Archivistics and Document Management, Journalism and Social Communication, Philosophy, History, History of Arts, Church Music, Family Sciences, Protection of Cultural Goods, Social Work, Historical Tourism, Religious Tourism, Canon Law, Theology; ${ }^{59}$ then the doctoral studies: of Philosophy (in English and in Polish), of History, in Media Sciences, in Family Sciences, in Theology, ${ }^{60}$ and also post-graduate diploma studies: Media Relations, Philosophy in Business, Creative Social Media, Social Economy Manager, Pastoral Studies of Permanent Formation of Priests, "Symbolism in the cultures of the world", Specialist Working with the Elderly in the Home and Institutional Environment, of Archivistics and Library Studies, of Bioethics, of Philosophy and Ethics, of Civil and Family Mediation, of the Liturgical Monody, of Theology with Specialization in Ecclesiology, Media and Culture Management, of the Team's Pastoral Care of St. John of God. ${ }^{61}$

The development of the University in its structural dimension is visible in the creation of new units. In the reported period the following ones can be mentioned. Radio Bonus has been aired around the clock with a regular webcast since November 19, 2010. Its mission is to promote the University and its activity. It cooperates among others with Radio Vatican, Catholic Information Agency

${ }^{58}$ Chronica 42 (2010), p. 454s., Chronica 50 (2018), p. 370.

${ }^{59}$ http://rekrutacja.upjp2.edu.pl/rekedumod/kierunki?type=1 (August 31, 2019), http:// rekrutacja.upjp2.edu.pl/rekedumod/kierunki?type=2 (August 31, 2019).

${ }^{60} \mathrm{http}: / /$ rekrutacja.upjp2.edu.pl/rekedumod/kierunki? \&type=4\&year=2018 (August 31, 2019).

${ }^{61} \mathrm{http} / / /$ rekrutacja.upjp2.edu.pl/rekedumod/kierunki? \&type=5\&year=2018 (August 31, 2019). 
sound service and the national radio stations. ${ }^{62}$ The university television station called "JP2TV" is a project realized at the Faculty of Social Sciences. It started its activity in October 2014. JP2TV has a website with visual materials created by the students of journalism and social communication. ${ }^{63}$ A special experience for students involved in JP2TV was World Youth Day in Krakow on July 30, 2016. ${ }^{64}$ The Association of the Graduates of the Pontifical University of John Paul II in Krakow "Academia Nostra" has been founded in 2011 and is open for those who once studied at the Faculty of Theology in Krakow, later at the Pontifical Academy of Theology and presently at the Pontifical University of John Paul II in Krakow. Its purpose is to strengthen the bonds between persons associated with our University and to promote their academic achievements. ${ }^{65}$ In 2016 the association has been changed to "The Association of Graduates and Friends of the Pontifical University of John Paul II" ${ }^{36}$. The Academic Incubator of Entrepreneurship helps students to develop and to run their own business (since October 1, 2014). It cooperates with the Academic Incubators of Entrepreneurship Foundation. The Incubator is part of our University's Career Office. ${ }^{67}$ The University of the Third Age has been dynamically expanding its activity at our University since academic year 2011-2012. It aims to increase knowledge among senior citizens. Around 500 people use this study opportunity. ${ }^{68}$ The Pontifical University of Children and Parents (since November 7, 2015) is an initiative open to children, youths, and their parents. ${ }^{69}$ The University Christian Outreach (UCO) community since December 2016 has functioned as the second academic ministry at our University. Its aims can be expressed in three challenges: "Live life to the fullest!" "Pass it on!" and "Grow!"7o

${ }^{62}$ Chronica 44 (2012), p. 344. Cf. http://radiobonus.pl/ (August 31, 2019).

${ }^{63}$ Chronica 46 (2014), p. 352. Cf. http://jp2tv.pl/ (August 31, 2019).

${ }^{64}$ Chronica 49 (2017), p. 441s.

${ }^{65}$ Chronica 46 (2014), p. 356.

${ }^{66}$ Chronica 50 (2018), p. 377. Cf. http://saip.upjp2.edu.pl/ (August 31, 2019).

${ }^{67}$ Chronica 47 (2015), p. 318, 49 (2017), p. 445. Cf. http://upjp2.edu.pl/node/918 (August 31, 2019).

${ }^{68}$ Chronica 48 (2016), p. 449. Cf. http://upjp2.edu.pl/node/739 (August 31, 2019).

${ }^{69}$ Chronica 48 (2016), p. 449. Cf. http://upjp2.edu.pl/komunikaty/rusza-papieskiuniwersytet-dzieci-i-rodzic\%C3\%B3w (August 31, 2019).

${ }^{70}$ Chronica 49 (2017), p. 444s. Cf. https://ucokrakow.pl/ (August 31, 2019). 
One of the most important events of the last ten years was undoubtedly the moving of the Main Library collection from the old place of storage, which was the building of the Archdiocesan Seminary in Krakow at 8 Podzamcze Street. The job was completed by the end of 2010. Most books in the new library are now directly available, which involves also the need for assuring adequate security of each book. The construction of the Library at 10 Bobrzyńskiego Street on the university campus is a very significant investment of the University which requires large financial means. Construction of didactic, scientific and research buildings in the immediate vicinity of the Library will start in a few months. $^{71}$

Our university's main library is a specialist one. It participates in the development of the national library information exchange system as well as in the work of the Krakow Library Group, the Central Catalog of Polish Academic Libraries NUKAT, and the Federation of Polish Church Libraries FIDES. The library continues to expand its digital catalog in the VTLS/Virtua integrated information system. As of October1, 2010, the number of volumes was 142,864 book entries and 3,937 entries of periodicals, while at same time in 2018, the number of volumes was 236,842 , while the number of records of continuously published publications was 5,422. This catalog is available online as a database. In the years 2010-2018 the library gained 78,423 volumes of books. In 2010 the Library had a total of 581,738 publications in stock, while in $2018-660,161$. The number of regular library cardholders in 2010 was 7,982, while in 2018 it was 12,122 (as of October 1, 2018). ${ }^{72}$

The library provides the access to those databases that require licenses. It is available for our staff, undergraduates, and doctoral students not only from the computers of the main library, but also at home after logging in. The library offers access to the following economic databases: ABE-IPS Books Online Journals, ATLA Religion Database with ATLA Serials, Communication \& Mass Media Complete, Cambridge Journals - collection HSS, JSTOR - collections Arts \& Sciences III, Arts \& Sciences XIII, and Religion \& Theology. Additionally, our university's computer network makes it possible to access databases financed by the Ministry of Science and Higher Education as part of the Virtual Library of Science. It includes IBUK Libra, a service belonging to Polish Scientific Publishers PWN, which makes publications available in electronic form (it

\footnotetext{
${ }^{71}$ Cf. Chronica 42 (2010), p. 458.

${ }^{72}$ Cf. Chronica 42 (2010), p. 457s., Chronica 50 (2018), p. 377.
} 
has existed since 2007). The library also makes access from the most important databases possible: Elsevier, Springer, Web of Science (produced by Thomson Reuters, which also includes access to the Web of Knowledge database), Nature, Science, Scopus, Wiley-Blackwell, and EBSCO Host. ${ }^{73}$

The results of the university's "service of thought" are available in publications. The Academic Press (Wydawnictwo Naukowe) gives this opportunity above all to the University's research and teaching staff by publishing not only periodicals but also books. Of course, scientists also publish their numerous works in many others publishing houses. A university-wide publication that has regularly appeared since 1969 is "Analecta Cracoviensia", which contains studies in the areas of philosophy, theology, Church history, canon law, and the social sciences. Fifty volumes of this journal have already been published (fifty years, including three double volumes). In addition to "Analecta Cracoviensia", each faculty has its own journal: "Polonia Sacra" is a journal published by the Faculty of Theology (so far, twenty-three volumes have been published), which since 2013 also publishes the English-language journal "Theological Research. A Journal of Systematic Theology" (five volumes have been published so far). "Logos i Ethos" ("Logos and Ethos") is a journal published by the Faculty of Philosophy (forty-eight volumes have been published since 1991), while the Faculty of Church History publishes "Folia Historica Cracoviensia" (twenty-four volumes) and "Textus et Studia" (since 2015, nine volumes have been published), "Pro Musica Sacra" (since 2004, sixteen volumes have been published), and "Orientalia Christiana Cracoviensia" (since 2009, ten volumes have been published). The Faculty of Social Sciences publishes "Studia Socialia Cracoviensia" (since 2009, ten volumes have been published). The Faculty of Canon Law publishes "Annales Canonici" (so far, fourteen volumes have been published). The Faculty of Theology - Theological Section in Tarnow has two journals: "Tarnowskie Studia Teologiczne" (since 1938, thirty-seven volumes have been published) as well as "The Person and the Challenges" (since 2011, nine volumes have been published). The Center for Interdisciplinary studies at the Faculty of Philosophy publishes „Zagadnienia Filozoficzne w Nauce” ("Philosophical Topics in Science"). This is a semi-annual journal that deals with the discovery and analysis of philosophical problems intertwined with the natural sciences (so far, sixty-six volumes have been published). "Semina Scientiarum”, initially published as a supplement to the aforementioned „Zagadnienia Filozoficzne

${ }^{73}$ Cf. Chronica 50 (2018), p. 377s. 
w Nauce", are a similar journal. It is edited by participants of the Academic Seminar in the Philosophy of Science and is devoted to topics at the intersection of philosophy and the natural sciences (so far, sixteen volumes have been published). Since 2011, the Faculty of Philosophy has published the journal „Racjonalia. Z punktu widzenia humanistyki” ("Rationalia: From the Perspective of the Humanities"), edited by our University's Philosophy Study Circle. It publishes papers by our students of all three cycles of studies, participants in post-graduate studies, and the academic staff of post-secondary universities (so far, seven volumes have been published). With the exception of the journal „Zagadnienia Filozoficzne w Nauce”, all are published on our university's Digital Platform. ${ }^{74}$

Our University's official informative journal is "Vita Academica: The Information Bulletin of the Pontifical University of John Paul II", which appears every three months and contains information related to the most important events in our University's life. ${ }^{75}$

Book series are also available as regular publications. One of them, which is particularly worth mentioning, are Studia nad Myśla Jana Pawła II ("Studies on the Thought of John Paul II"), edited by the Center for Studies on the Thought of John Paul II. So far, the Center has published eighteen volumes in this series. The other series are: Biblioteka Ekumenii i Dialogu ("The Library of Ecumenism and Dialouge"); Duc in Altum ("Put out into Deep"); Duchowość Klasztorów Polskich: Przekaz i Komunikacja ("The Spirituality of Polish Monasteries: Message and Communication"); Etyka i Życie Publiczne ("Ethics and Public Life"); Hermeneutica et Iudaica ("Hermeneutics and Hebrew Studies"); Annales Canonici Monographiae ("Yearbooks of Canon Law - Monographs"); Studia do Dziejów Wydzialu Teologicznego ("Studies on the History of the Faculty of Theology"); Podręczniki Wydziału Teologicznego ("Textbooks of the Faculty of Theology"); Studia, Prace i Sympozja ("Studies, Papers and Symposiums"); Ad Dominum ("To the Lord"); Biblijne Wezwania do Rozwijania Kultury ("Biblical Calls for the Development of Culture"); Symbol - Znak - Przesłanie ("Symbol - Sign - Message"); Znak - Symbol - Rytuat ("Sign - Symbol - Ritual"). In addition to regular publications, many single books have also been issued. Throughout the years

${ }^{74}$ http://czasopisma.upjp2.edu.pl/index/index (August 31, 2019), https://zfn.edu.pl/index. php/zfn/index (August 31, 2019). Cf. Chronica 50 (2018), p. 372 s.

${ }^{75}$ Chronica 50 (2018), p. 373, http://upjp2.edu.pl/node/1014 (August 31, 2019). 
2009-2018, our Academic Press published in total five hundred seventy-four publications, including one hundred forty-five issues of journals. ${ }^{76}$

A new way of publishing are the university's websites. Our academic Press systematically increases the number of publications available online, namely in our University's Repository ${ }^{77}$ and in a digital Platform of Journals ${ }^{78}$ where our journals are made available (fourteen at the time of writing).

The University's development is supported by the Saint Queen Jadwiga Foundation for the Pontifical University of John Paul II in Krakow (from February 2, 1990). According to the statute, the Foundation provides financial support to our University "in its academic and artistic activities". It is true that the university receives funds from the state budget that cover 72 percent of the university's expenditure on current operations, but they do not cover investment costs at all. The remaining financial resources must therefore be covered from other sources. The University and the Foundation are very grateful to the donors for all their support. ${ }^{79}$

To sum up, it can be said that the information provided above shows the University's significant contribution to the development of understanding and transmission of the Church's teaching in the modern world. Scientific and popularizing publications are a service of truth in its many dimensions. Graduation and promotion of scientists enrich the Church and civil society with people capable of serving the truth, "ready to make a defense to everyone who asks [them] to give an account for the hope that is in [them]" (1 Pt 3:15), and able to perform "the service of thought".

${ }^{76}$ Chronica 41 (2009), p. 533; 42 (2010), p. 456; 43 (2011), p. 426; 44 (2012), p. 345; 45 (2013), p. 387; 46 (2014), p. 353; 47 (2015), p. 316; 48 (2016), p. 454; 49 (2017), p. 443; 50 (2018), p. 374.

${ }^{77}$ http://bc.upjp2.edu.pl/dlibra (August 31, 2019).

${ }^{78}$ http://czasopisma.upjp2.edu.pl/index/index (August 31, 2019).

${ }^{79}$ Chronica 50 (2018), p. 378. Cf. http://upjp2.edu.pl/uczelnia/uczelnia/instytucje/fundacjaim-\%C5\%9Bw-kr\%C3\%B3lowej-jadwigi (in Polish and in English (August 31, 2019). 


\section{Bibliography}

\section{a. Printed sources}

International Conference. The Role of the Catholic Church in the Process of European Integration. Review of Events. Cracow 2001-2017, eds. R. Budnik, M. Góra, Gliwice: Wydawnictwo „Wokół nas” 2018, pp. 76 (ISBN 978-83-88199-73-8).

Szczurek Jan D., Moving to the Campus. 613th Academic Year at the Pontifical University of John Paul II in Krakow, "Analecta Cracoviensia" 42(2010), p. 431-460 (Chronica).

Szczurek Jan D., Beatification of the University Founder.614th Academic Year at the Pontifical University of John Paul II in Krakow, "Analecta Cracoviensia" 43(2011), p. 403-430 (Chronica).

Szczurek Jan D., The Gratitude of the University. 615th Academic Year at the Pontifical University of John Paul II in Krakow, „Analecta Cracoviensia” 44(2012), p. 323-349 (Chronica).

Szczurek Jan D., Pursuing the Faith. 616th Academic Year at the Pontifical University of John Paul II in Krakow, „Analecta Cracoviensia” 45(2013), p. 355-390 (Chronica).

Szczurek Jan D., The Canonization of the University Patron. 617th Academic Year at the Pontifical University of John Paul II in Krakow, „Analecta Cracoviensia” 46(2014), p. 315-360 (Chronica).

Szczurek Jan D., In Gratitude to Pope Emeritus Benedict XVI During the 618th Academy Year at the University, „Analecta Cracoviensia” 47 (2015), p. 253-323 (Chronica).

Szczurek Jan D., Farewell to the First Great Chancellor. 619th Academic Year at the Pontifical University of John Paul II in Krakow, „Analecta Cracoviensia” 48 (2016), p. 401-461 (Chronica).

Szczurek Jan D., In the service of the truth. 620th Academic Year at the Pontifical University of John Paul II in Krakow, „Analecta Cracoviensia” 49 (2017), p. 391-451 (Chronica).

Szczurek Jan D., Euntes docete. 621st Academic Year at the Pontifical University of John Paul II in Krakow, „Analecta Cracoviensia” 50 (2018), p. 305-381 (Chronica).

\section{b. Websites}

John Paul II, Meeting with the Rectors of the Polish Universities. Address, no. 3, Collegiate Church of Saint Ann (8 June 1997), http://w2.vatican.va/content/john-paul-ii/en/ speeches/1997/june/documents/hf_jpii_spe_19970608_ato-academico.html (July 22, 2019).

http://upjp2.edu.pl/uczelnia/x-uroczysta-inauguracja-roku-akademickiego-20182019-upjpii (August 23, 2019).

http://www.kosciol-europa.org.pl/wp-content/uploads/krakow2018-EN.pdf (1.08.2019). http://www.upjp2.edu.pl/sites/default/files/materialy/broszura\%20konferencyjna\%20 2001-2017\%282\%29\%281\%29.pdf (August 26, 2019).

http://www.upjp2.edu.pl/konferencje-sesje/perspektywy-rozwoju-unii-europejskiej\%E2\%80\%93-xviii-mi\%C4\%99dzynarodowa-konferencja-rola (August 26, 2019). 
http://www.copernicuscenter.edu.pl/en/conferences/ (August 29, 2019).

http://wf.upjp2.edu.pl/sites/default/files/Sprawiedliwo\%C5\%9B\%C4\%87\%20w\%20 \%C5\%BCyciu\%20publicznym\%20-\%20program.pdf (August 30, 2019).

http://upjp2.edu.pl/konferencje-sesje/zmartwychwsta\%C5\%84cy-i-odrodzenie-ojczyzny\%E2\%80\%93-xvii-og\%C3\%B3lnopolska-konferencja-naukowa-z (August 30, 2019). http://www.upjp2.edu.pl/konferencje-sesje/xiii-konferencja-naukowa-etyki-medi\%C3\%B3w22-\%E2\%80\%93-23-v-2019 (August 30, 2019).

https://krakowmeetings.eu/conferences (August 30, 2019).

http://www.upjp2.edu.pl/konferencje-sesje/i-mi\%C4\%99dzynarodowa-konferencjanaukowa-tradycje-i-obyczaje-w-kulturach-i-religiach (August 31, 2019).

http://rekrutacja.upjp2.edu.pl/rekedumod/kierunki?type=1 (August 31, 2019).

http://rekrutacja.upjp2.edu.pl/rekedumod/kierunki?type=2 (August 31, 2019).

http://rekrutacja.upjp2.edu.pl/rekedumod/kierunki?\&type=4\&year=2018 (August 31, 2019). http://rekrutacja.upjp2.edu.pl/rekedumod/kierunki?\&type=5\&year=2018 (August 31, 2019). http://radiobonus.pl/ (August 31, 2019).

http://saip.upjp2.edu.pl/ (August 31, 2019).

http://upjp2.edu.pl/node/918 (August 31, 2019).

http://upjp2.edu.pl/node/739 (August 31, 2019).

http://upjp2.edu.pl/komunikaty/rusza-papieski-uniwersytet-dzieci-i-rodzic\%C3\%B3w (August 31, 2019).

https://ucokrakow.pl/ (August 31, 2019).

http://czasopisma.upjp2.edu.pl/index/index (August 31, 2019).

https://zfn.edu.pl/index.php/zfn/index (August 31, 2019).

http://bc.upjp2.edu.pl/dlibra (August 31, 2019).

http://czasopisma.upjp2.edu.pl/index/index (August 31, 2019).

http://upjp2.edu.pl/uczelnia/uczelnia/instytucje/fundacja-im-\%C5\%9Bw-kr\%C3\%B3lowejjadwigi (August 31, 2019). 